\title{
SATISFACTION WITH DWELLING UNIT ATTRIBUTES AND INFRASTRUCTURE WITHIN SELECTED PUBLIC HOUSING ESTATES IN NORTHERN NIGERIA
}

\author{
Joy Maina ${ }^{1,2^{*}}$, Musa Dagoli ${ }^{2}$, Abdulrazak Abdulkadir ${ }^{2}$, Nurudeen Muhammad ${ }^{2}$, Isa \\ Muhammed $^{2}$, Bukhari Yusuf ${ }^{2}$, Ternenge Mtan $^{2}$, Mahmud Abdulrazaq ${ }^{2}$ \\ ${ }^{1}$ Research and Innovation Unit, Directorate of Academic Planning and Monitoring, \\ Ahmadu Bello University, Zaria-Nigeria \\ ${ }^{2}$ Department of Architecture, Ahmadu Bello University, Zaria-Nigeria
}

(Received: February 2021 / Revised: March 2021 / Accepted: April 2021)

\begin{abstract}
This study assessed satisfaction with dwelling unit attributes as well as support services and infrastructure within public housing estates across Northern Nigeria as such studies are rare in literature but important for design and policymaking. Results of descriptive statistics, Principal Component Analyses and Regression from 125 respondents in Abuja, Dutse, Sokoto, Gombe and Potiskum revealed that support services and infrastructure notably water supply and waste disposal were inadequate. Although residents were fairly satisfied with their dwelling units (M 3.13), water supply influenced satisfaction ratings for service-related spaces including baths, toilets, cooking and storage. Other areas of dissatisfaction were number of bedrooms, quality of construction and sizes of living spaces. Residents were most satisfied with quality of natural lighting, ventilation, location of houses, noise as well as privacy levels. Results from PCA revealed that residents view satisfaction with their dwelling unit attributes and infrastructure in terms of design and cost, services and indoor environmental quality as well as electricity supply and noise levels. These three factors emerged as significant predictors of satisfaction with dwelling unit attributes and infrastructure, $F(20.54,18), \mathrm{p}=0.000, \mathrm{R}^{2}=0.777$, in a model that included tenant characteristics. Findings imply that inadequacy in water supply requires urgent attention within public housing estates in the region. Importantly, user perception in terms of the three predictors of satisfaction ought to guide design of future dwelling units within public housing estates in Northern Nigeria.
\end{abstract}

Keywords: Dwelling units; Infrastructure; Northern Nigeria; Public Housing; Satisfaction

\section{INTRODUCTION}

Housing is a critical component of sustainable and resilient built environments especially in developing countries where rapid urbanisation largely owing to migration from rural to urban areas threatens the stability of existing infrastructure, housing and its support services. Hussaini et al., (2019) note that Africa is the fastest urbanising continent and that urbanisation in Sub Saharan Africa is characterised by the influx of poor people into urban areas. Urbanet (2018) asserts that the urban population "has been experiencing a rapid rise since 2010 and is expected to grow from 60 million to almost 300 million inhabitants in Nigerian cities".

*Corresponding author's email: jjmaina@abu.edu.ng

DOI: https://doi.org/10.32783/csid-jid.v4i1.211 
The report confirms that as at 2018, forty of Nigeria's cities have a population between 300,000 and 1 million inhabitants. Out of these, nine medium-sized cities are home to between 1 and 5 million residents with Lagos accommodating more than 10 million people.

These statistics invariably affect housing and its support infrastructure as urbanisation is closely linked to problems of planning, inadequate provision of housing, basic infrastructure and amenities (Eziyi Offia Ibem \& Aduwo, 2013; Morakinyo et al., 2014; Zaki, Y.M. et al., 2015). The lack of such vital infrastructure produces slums proliferating many urban areas in Nigeria. To minimise pressure on existing facilities and ensure that the quality of existing housing stock is not compromised, urban and housing experts need to consider pertinent issues in the design of new housing schemes, notably the provision of basic urban services that meet specific requirements of residents (Equere et al., 2020).

To this end, several studies assess the adequacy of existing housing environments holistically using satisfaction ratings from residents (Adegbile et al., 2020; Babalola et al., 2019; Eziyi Offia Ibem, 2013; Omolabi, 2018; Wakuma Kitila, 2019). Etminani-Ghasrodashti et al. (2017) however observe that most studies focus on physical attributes of housing units as influential factors determining overall residential satisfaction. Such attributes include level of thermal/visual comfort, size of living/sleeping areas, noise and privacy, light, ventilation, sizes of housing units as well as housing services (Eziyi O. Ibem \& Amole, 2013; Eziyi Offia Ibem \& Aduwo, 2013; Eziyi Offia Ibem \& Alagbe, 2015). All of the aforementioned studies were conducted in Southern parts of Nigeria, with little comparative investigations conducted in Northern regions. It is often unclear which attributes of dwelling units and their support infrastructure are most critical in terms of satisfaction and adequacy from the perspective of end users in Northern Nigeria.

Investigating satisfaction and adequacy of dwelling unit attributes and supporting infrastructure is important for several reasons. First, the Nigerian government invests a large proportion of funds in housing. This trend projects into the near future as the Federal Government (FG) proposes to construct about 300,000 housing units across the nation as part of its COVID-19 palliative strategies (Nigerian Investment Promotion Comission, 2020). Secondly, the impact of direct modifications by individual residents in adapting to lifestyle changes are largely made at the micro level of dwellings, separate from communal efforts at neighbourhood level. Initiation of pressure on urban infrastructure and support often commences at dwelling unit level, thus making it worthy of study. Thirdly, design decisions of planned estates culminate at dwelling units but information regarding ways residents perceive adequacy through satisfaction ratings of attributes and support infrastructure at this level are rare. This is critical to inform and guide design even from inception where critical decisions are often made based on assumptions made by professionals' experience and intuition (Aragonés et al., 2017). Such decisions are often not approved by the residents, a reason proffered for the failure of many housing programs.

This study assesses satisfaction with dwelling unit attributes and support infrastructure to establish ways residents perceive adequacy of their housing at micro levels. This is to inform design and policy towards improvement of future projects and creation of more sustainable and resilient built environments in light of the challenges posed by urbanisation in Nigeria.

\section{LITERATURE REVIEW}

\subsection{Residential Satisfaction and Adequacy in Housing}

Residential satisfaction as a multidimensional construct measuring the extent people are happy with their housing environment and associated services (Eziyi Offia Ibem \& Aduwo, 2013). The concept is often employed as a measure of housing quality and adequacy (Eziyi Offia Ibem 
\& Alagbe, 2015). Two theoretical approaches frequently applied in residential satisfaction studies are Aspiration Gap (Galster, 1987) and Housing Adjustment theory (Morris \& Winter, 1975).

Aspirations Gap Approach posits that satisfaction depends on an individual's cognitive construct, a reference condition for salient features of housing environments depending on selfassessed needs and aspirations. "If the current situation is perceived to be in proximate congruence with the reference situation, an affective state of satisfaction should be manifested" (Galster, 1987). If present housing situations fail to meet this reference point, a family adapts by redefining its needs, altering the evaluation of current residential situation or by lowering its standards in order to reconcile aspirations and actual situations. The second alternative is for the family to manifest dissatisfaction with the current housing situation. Closely related to Aspirations Gap Approach is Housing Adjustment Theory, which posits that residents evaluate housing situations based on family and societal norms. "If the housing does not fit with normatively derived needs, a housing deficit is said to exist" (Morris \& Winter, 1975). This is likely to produce dissatisfaction. Morris and Winter (1975) assert that dissatisfied residents are likely to relocate to another house (residential mobility), change the family size or composition (family adaptation) or transform the house through adaptation, modification or alteration.

Several studies evaluate satisfaction with housing attributes and supporting urban infrastructure in Nigeria (Table 1) with the literature revealing four trends. First, satisfaction with housing attributes is a function of the quality of design and construction. Jiboye (2012) post-occupancy evaluation of housing units in Lagos reported that residential satisfaction was a function of the total physical characteristics of housing units. The initial high quality of construction as well as maintenance carried out by residents of the estate were reasons proffered in support of the findings. Good maintenance culture was associated to the high socio-economic status and educational attainments of residents (A. Oladapo, 2006). Consequently, residents were generally satisfied with the housing situation in the estate as were similar cases in Maiduguri (Mammadi et al., 2020), Ogun State (Adegbile et al., 2019) and Zaria (Maina et al., 2018). These results however contrast with findings submitted by Ukoha and Beamish (1997) Abuja were residents were dissatisfied with housing characteristics. This was largely because "structure types determine the availability of building features in dwelling units" (p. 458), resulting in dissatisfaction as features of the dwellings described in Table 1 failed to meet expectations of residents. Reports of dissatisfaction with dwelling unit features and support services also occurred in Lagos (Omolabi, 2018), Ibadan (Morakinyo et al., 2014) as well as in Osogbo (R. A. Oladapo \& Adebayo, 2014).

The second trend in literature suggests that adequacy of urban infrastructure depends on multiple factors, key among them being the quality of original construction, management and maintenance of said infrastructure. Oluwunmi et al. (2012) observed that residents were satisfied with housing support services and infrastructure at Covenant University largely due to huge investments by the institution in a bid to ensure maintenance of optimum services of diesel-powered generating sets to supplement epileptic public power supply as well as forty boreholes to augment water supply. Professional security operatives provide adequate surveillance cover to residents within the school's premises. Generally, dissatisfaction with support services was common in public estates compared to private estates in literature.

Thirdly, infrastructure directly supporting dwellings notably water supply, electricity supply and waste disposal were common areas of dissatisfaction especially among residents of public estates. Notable exceptions to these cases were findings by Adzande (2013) as well as Ukoha and Beamish (1997), the latter reporting highest satisfaction with water pressure from Table 1. 
Table 1 Studies on satisfaction with dwelling unit attributes and infrastructure in Nigeria

\begin{tabular}{ll}
\hline Author(s) & Purpose \\
\hline $\begin{array}{l}\text { Mammadi } \\
\text { et al. }\end{array}$ & $\begin{array}{l}\text { To assess residents' satisfaction } \\
\text { with public housing in Maiduguri }\end{array}$ \\
Adegbile & $\begin{array}{l}\text { To investigate influence of housing } \\
\text { attributes on housing satisfaction in } \\
\text { selected residential areas in Ogun }\end{array}$ \\
(2019) & $\begin{array}{l}\text { State } \\
\text { To investigate housing quality and } \\
\text { prospects for neighbourhood } \\
\text { revitalisation in public low-income } \\
\text { housing estates in Lagos }\end{array}$ \\
\end{tabular}

Maina et To investigate satisfaction of

al. (2018) residents with staff housing at Ahmadu Bello University Zaria

Fakere et To examine performance of al. (2018) infrastructural facilities in Akure

Zaki et al. To assess environmental conditions (2015) and conformity to housing standards within new settlements in Kaduna State

Morakinyo To evaluate housing infrastructural et al. (2014) provision in Bashorun housing scheme, Ibadan

Oladapo \& To examine effects of facilities on Adebayo residents' satisfaction in Osogbo

Ibem \& Aduwo

Adzande (2013)

Oluwunmi et al. (2012)

Ukoha \& Beamish (1997) services and facilities for urban residents in newly constructed public housing in Ogun State

To assess condition, residents' satisfaction and role of agencies in the provision of infrastructure in Nyiman layout, Makurdi

To investigate user satisfaction with residential facilities at Covenant University, Ota

To examine residents' satisfaction with public housing in Abuja
Key findings

Residents were very satisfied with components of public housing. Satisfaction was high with condition of bedrooms, living rooms, stores, kitchen, roof, finishes, toilets and dining areas

Residents were satisfied with space adequacy, sizes of rooms and building materials. More than $50 \%$ of residents were satisfied with dwelling unit attributes.

Residents were generally dissatisfied with housing design, sizes of living rooms and bedrooms, baths, roofs, exterior finishes/paint, ventilation, illumination, water and electricity supply, waste disposal, noise and sewage disposal. Residents were satisfied with toilets, kitchens, ceilings, walls and floors, rent and mortgage

Residents were most satisfied with housing attributes notably sizes of living and functional spaces, open areas/landscaping, lighting, air quality. Dissatisfaction was highest with water and power supply, waste management and sewage disposal

Residents found infrastructural facilities unsatisfactory. Satisfaction was highest with waste management and least with water supply

Low ranking of water supply implies inadequacy. Noncompliance to plot coverage standards resulted in congestion of surveyed areas

Dissatisfaction with household facilities, inadequate and poor water supply largely from wells; poor waste disposal, unstable power supply.

Residents in Isale Ogun were dissatisfied with water, electricity supply, toilets and refuse. Residents of Alekuwodo were satisfied with most facilities except refuse disposal

Residents had poor access to treated water, inadequate power supply
Assessment for development at street level was low implying inadequate provision of physical infrastructure. Residents were dissatisfied with refuse disposal but satisfied with water, electricity supply and sewage disposal

Residents were satisfied with electricity and water supply, security, lawn/flower maintenance, sanitation and waste disposal systems. Dissatisfaction occurred with fumigation service, maintenance and internet connectivity

Dissatisfaction with smaller typologies and most building features owing to poor construction (plumbing, lighting, doors, interior/exterior painting, sizes and number of rooms, study, storage and privacy). Satisfaction was highest with water pressure 
infrastructure only. Majority of studies on residential satisfaction in Nigeria investigate dwelling unit features as part of the larger system of housing environments based on the Housing Habitability Framework, made up of four subsystems-tenant, dwelling, environment and management illustrated in Figure 1.

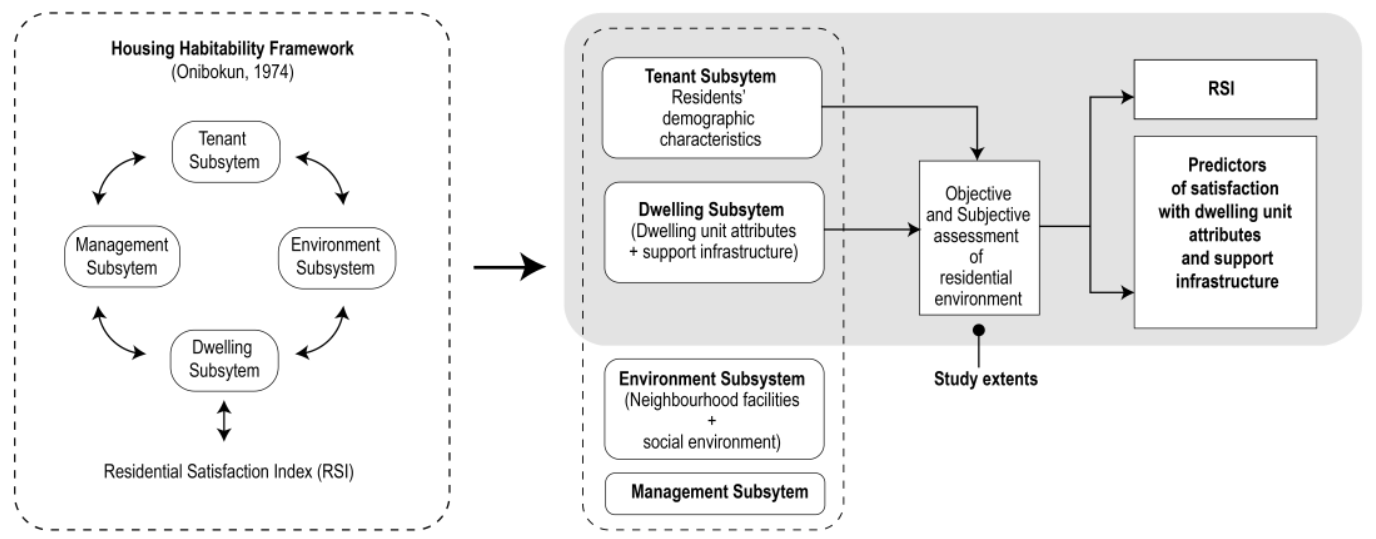

Figure 1 Conceptual framework of the study

This study investigates residents' satisfaction with dwelling units and supporting infrastructure via two research questions. First, which aspects of the dwelling subsystem are satisfactory or adequate and which aspects are not? Second, how do residents perceive the dwelling subsystem in terms of satisfaction ratings to guide future planning of similar estates in the study area?

\section{METHODOLOGY}

\subsection{Study Area}

Northern Nigeria comprises three geopolitical zones (Figure 2) covering an area of approximately $660,000 \mathrm{~km}^{2}$ of the country's total land mass of $923,768 \mathrm{~km}^{2}$ (World Bank, 2020). Two estates, in Dutse and Sokoto were selected in the Northwest region, while another two in Potiskum and Gombe represent the Northeast region. An estate was selected in Abuja representing the Northcentral region. Criterion for selection was that estates were procured and constructed using public funds and later allocated to civil servants on owner-occupier basis.

The estate in Dutse contains 2, 3 and 4-bedroom bungalows, while 2 and 3 bedroom bungalows make up the Sokoto sample. Similarly, the estate in Gombe comprises 2 and 3 bedroom bungalows, the former designed as semi-detached units while the latter are stand-alone bungalows. The estate in Potiskum contained the least population of 50 units consisting of 2 and 3 bedroom bungalows. In Abuja, dwellings were designed as 2 bedroom semi-detached bungalows. All dwelling units contain an open courtyard to accommodate diurnal activities of residents in the hot-dry savanna climate common across Northern Nigeria.

Sample size $(n)$ was calculated as a ratio of total population $(N)$ and $1+N\left(e^{2}\right)$ where $e$ represents 0.05 margin of error (Bixley \& Yamane, 1965). This produced an overall sample size of approximately 280, with samples for individual estates computed pro-rata (Table 2). We encountered tremendous problems during the survey in estates located in the Northwest region particularly Sokoto due to high levels of insecurity and banditry across the region at the time of the study in 2019 (Lar, 2019). 


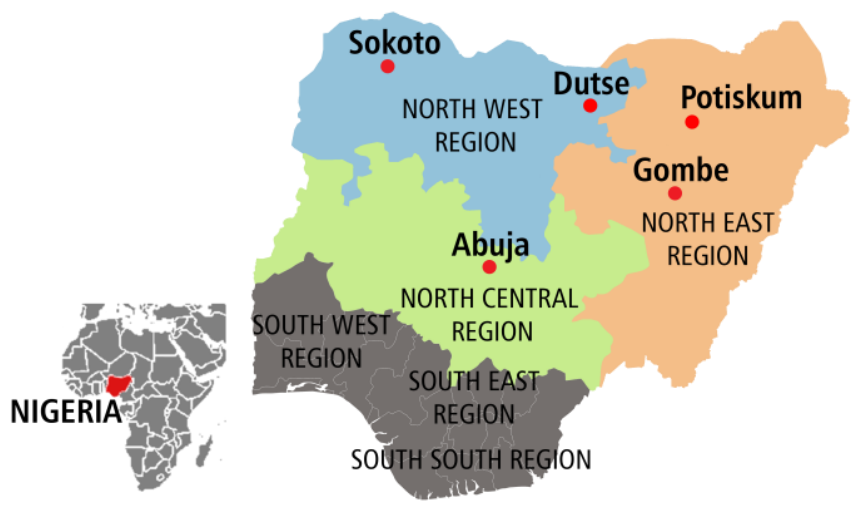

Figure 2 Location of Study areas

Sociocultural and religious restrictions further compounded the situation (Maina et al., 2018). With the aid of locally sourced field assistants, 235 questionnaires were eventually distributed. Respondents granted their consent prior to the survey. Overall, 125 questionnaires (45\% of the sample size) were retrieved and found valid for analyses. This was above the minimum $30 \%$ acceptable return rate expected for construction related research (A. Oladapo, 2006).

Table 2 Population and sample size

\begin{tabular}{lllll}
\hline Location of Estate & Population $(N)$ & Sample & Distributed & Valid \\
\hline Gombe & 115 & 35 & 55 & 35 \\
Potiskum & 50 & 17 & 50 & 23 \\
Dutse & 200 & 60 & 50 & 27 \\
Sokoto & 500 & 150 & 50 & 23 \\
Abuja & 60 & 18 & 30 & 17 \\
Total & 925 & 280 & 235 & 125 \\
\hline
\end{tabular}

\subsection{Dataset and Analyses}

The research employed a questionnaire survey to address the study aim. Adapted from Ibem et al. (2017), the questionnaire contained three sections. Section A comprises ten sociodemographic variables describing the tenant subsystem. These include gender, marital status, age, education, income, employment sector, length of stay, household size, number of bedrooms and tenure status. These were analysed using descriptive statistics and presented in Table 3. Section B requested data on predominant sources of dwelling support infrastructure namely water supply, electricity supply and waste disposal. These were analysed using simple counts and percentages, with results presented in Figures 3-5 respectively. Section C contained 15 variables describing the dwelling subsystem comprising variables in Table 4 . Rent/cost of acquiring a house was included in the list because affordability is a serious concern for sustainability of housing and support infrastructure (Durodola et al., 2016). Data from this section was analysed in two ways to address research questions posed by the study.

To address the first question, data in form of satisfaction ratings from respondents were analysed for relative satisfaction index (RSI) calculated for each variable as a ratio of the sum of actual Satisfaction Scores ( $\mathrm{SS}_{\mathrm{ac}}$ ) and maximum possible Satisfaction Score (PSS $\mathrm{Pax}_{\text {) }}$ ) on a 5 point likert scale from 1 (very dissatisfied, VD) to 5 (very satisfied, VS) in Equation 1. For 125 questionnaires, PSS $_{\max }$ equals 625. 


$$
R S I=\frac{\Sigma S S_{a c}}{P S S_{\max }}
$$

A variable was considered satisfactory (and adequate) if its RSI was above 0.6 (Ogu, 2002). RSI scores below this value were dissatisfactory and therefore inadequate (Table 4). Data from this section also produced mean Dwelling Unit Satisfaction Scores (DUSS) for each respondent and for the entire sample. The overall cut-off point was set at 3.0, this value being the mid-point of a 5-point likert scale. These were instrumental in addressing research question two via two sets of analyses.

First, Principal Components Analysis (PCA) with Varimax rotation reduced the 15 dwelling unit variables into three components. These represent viewpoints of residents with dwelling unit attributes and support infrastructure in terms of satisfaction and adequacy ratings (Table 5). Kaiser-Meyer-Olkin measure of sampling adequacy was 0.789 , above the minimum expected value of 0.5 (Field, 2013). Secondly, CATREG regression was employed to establish predictors of satisfaction with DUSS from both tenant and dwelling subsystem variables (Table 6). CATREG analysis was employed in this study because it is suitable for analyses of nominal, ordinal and numerical data in small samples compared to other general linear regression models (Eziyi Offia Ibem \& Alagbe, 2015). The next section presents results from all of these procedures.

\section{RESULTS AND DISCUSSION}

\subsection{Demographic Profile of Respondents}

Results from Section A of the questionnaire revealed that larger proportions of respondents were male $(82,66 \%)$, married $(89,71 \%)$, aged $31-60$ years $(87,70 \%)$, tertiary degree holders $(78,62 \%)$ and mid-income earners $(54,43 \%)$. Respondents were also largely employed in the public sector $(70,56 \%)$, resident for $1-5$ years in the estates $(57,46 \%)$ and accommodate household sizes of $1-4$ persons $(52,42 \%)$ within 3 bedroom houses $(53,43 \%)$. Three-quarters of the sample $(93,75 \%)$ also own their dwellings. These statistics imply that respondents are qualified to provide the required information being familiar with the housing environment. Demographic data also fit the expected profiles of household heads living within public housing estates in Nigeria from literature (Eziyi Offia Ibem \& Alagbe, 2015).

Table 3 Demographic profile of respondents

\begin{tabular}{lll}
\hline Variable & Frequency (n 125) & $\%$ \\
\hline Gender & 82 & $66 \%$ \\
Male & 31 & $25 \%$ \\
Female & 12 & $9 \%$ \\
No response & & \\
Marital status & 89 & $71 \%$ \\
Married & 22 & $18 \%$ \\
Single & 14 & $11 \%$ \\
No response & & \\
Age in years & 3 & $2 \%$ \\
Up to 18 & 33 & $26 \%$ \\
18-30 & 87 & $70 \%$ \\
$31-60$ & 2 & $2 \%$ \\
60+ & & $16 \%$ \\
Educational qualification & 20 & \\
O'Levels & & \\
\hline
\end{tabular}




\begin{tabular}{|c|c|c|}
\hline Diploma & 21 & $17 \%$ \\
\hline Degree & 78 & $62 \%$ \\
\hline No response & 6 & $5 \%$ \\
\hline \multicolumn{3}{|c|}{ Monthly income in Naira } \\
\hline Less than 18,000 & 15 & $12 \%$ \\
\hline $18-50,000$ & 30 & $24 \%$ \\
\hline $51-150,000$ & 54 & $43 \%$ \\
\hline $150,000+$ & 17 & $14 \%$ \\
\hline No response & 9 & $7 \%$ \\
\hline \multicolumn{3}{|l|}{ Employment } \\
\hline Public sector & 70 & $56 \%$ \\
\hline Private sector & 45 & $36 \%$ \\
\hline Retiree & 6 & $5 \%$ \\
\hline No response & 4 & $3 \%$ \\
\hline \multicolumn{3}{|l|}{ Length of stay } \\
\hline Less than 1 year & 19 & $15 \%$ \\
\hline $1-5$ years & 57 & $46 \%$ \\
\hline $6-10$ years & 21 & $17 \%$ \\
\hline $10+$ & 26 & $21 \%$ \\
\hline No response & 2 & $1 \%$ \\
\hline \multicolumn{3}{|l|}{ Household size } \\
\hline 1-4 persons & 52 & $42 \%$ \\
\hline $5-6$ persons & 36 & $29 \%$ \\
\hline $6+$ & 35 & $28 \%$ \\
\hline No response & 2 & $1 \%$ \\
\hline \multicolumn{3}{|c|}{ Number of bedrooms } \\
\hline 2 & 48 & $38 \%$ \\
\hline 3 & 53 & $43 \%$ \\
\hline 4 & 17 & $14 \%$ \\
\hline Above 4 & 3 & $2 \%$ \\
\hline No response & 4 & $3 \%$ \\
\hline \multicolumn{3}{|l|}{ Tenure } \\
\hline Owner-occupier & 93 & $75 \%$ \\
\hline Renter & 30 & $24 \%$ \\
\hline No response & 2 & $1 \%$ \\
\hline
\end{tabular}

Information from Section B illustrates that boreholes present the most predominant source of water supply accounting for 35\% ( $\mathrm{n} 44$ ) of responses in Figure 3. These are followed by vendors $(38,30 \%)$, wells $(21,17 \%)$ and lastly, pipe-borne public water supply $(18,14 \%)$. These figures support Fakere et al. (2018) who submit that public water supply in many Nigerian urban areas is inaccessible and unreliable, largely dependent on self-help alternatives by residents.

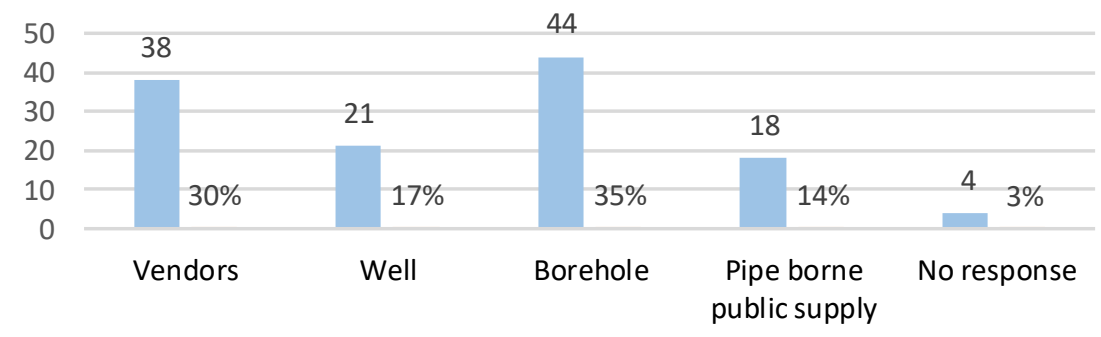

Figure 3 Predominant source of water supply 
In contrast, data from Figure 4 illustrates that public power supply is the most predominant source of electricity supply across the regions, accounting for $48 \%$ (n 60) of responses. Supply from solar panels $(45,36 \%)$ follow. Generating sets $(18,14 \%)$ record the lowest frequencies from the sample. This reveals a marked improvement in public power supply in recent times as generating sets were the predominant source of electric power supply for many residents in Nigeria according to Stanley et al. (2016).

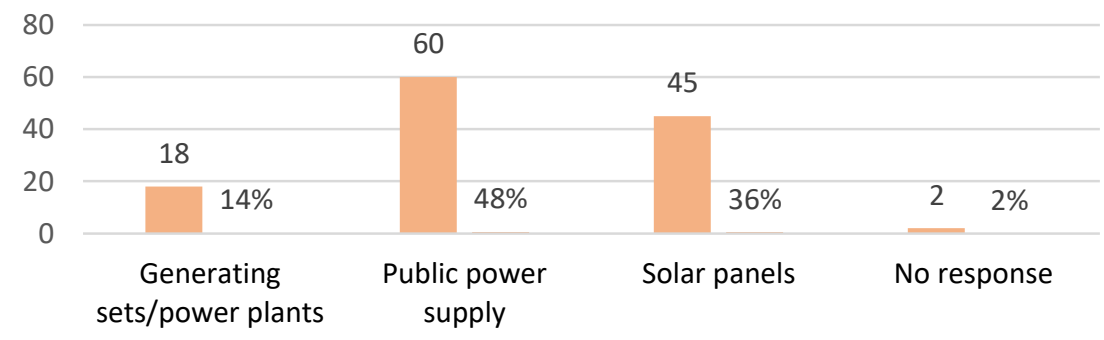

Figure 4 Predominant source of electricity/power supply

Figure 5 illustrates that contractors $(57,46 \%)$ are largely responsible for disposing waste across the sample. A sizeable proportion of residents $(41,33 \%)$ however dispose their own waste. Estate managers as well as government agents (8, 6\% each) record lower figures for responsibility of waste disposal.

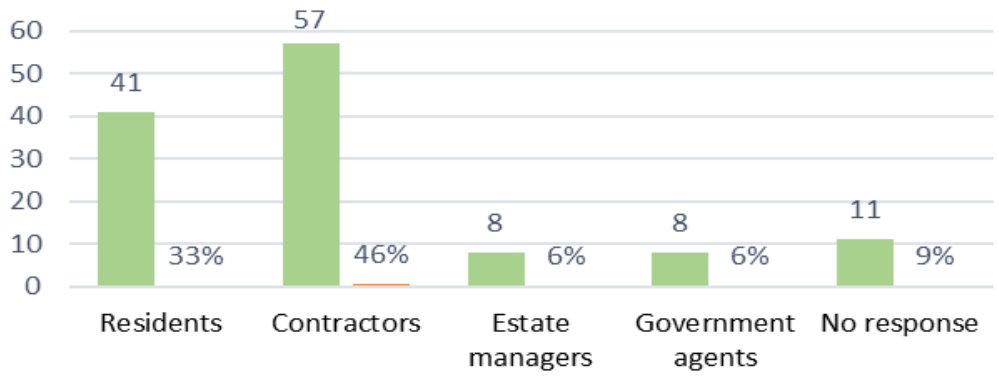

Figure 5 Responsibility for waste disposal

Overall, objective statistics from dwelling unit support services and infrastructure reveal that water supply is a common problem across the sample. This is unlike electricity supplied through public power lines, although results on the latter suggests that solar panels supplement power supply across the sample (Figure 4). This is a commendable trend towards sustainability and use of alternative energy sources. Nonetheless, results imply that basic support services and infrastructure notably water and to some extent, power supply depend largely on personal efforts made by residents. In the case of water supply, boreholes and wells predominate the sample. Results reveal that the situation may be better in the case of waste disposal (Figure 5) with evidence of organised formal waste disposal avenues in the form of contractors. Visual observations during the survey however revealed that residents employed pockets of open areas to dispose household waste with attendant health risks to communities within the estates.

\subsection{Satisfaction with Dwelling Unit Attributes and Infrastructure}

In response to research question one, nine variables recorded RSI values above 0.6. Presented in Table 4, the first seven variables relate to design and planning attributes of dwelling units. These include natural lighting and ventilation, location of the house, levels of noise and privacy, sizes of bedrooms, external appearance of the house as well as the typology, largely based on the number of bedrooms in the house. The other two variables are electricity supply and affordability issues in form of rent/cost of acquiring the house. These findings contrast to 
results submitted by Salisu et al. (2019) where residents of public housing in Lagos were most dissatisfied with the physical aspects of their dwelling units, underscoring the observation that residential satisfaction is contextual.

Table 4 Descriptive for dwelling unit attributes and infrastructure

\begin{tabular}{|c|c|c|c|c|c|c|c|c|c|}
\hline & VD & $\mathrm{D}$ & $\mathrm{N}$ & $\mathrm{S}$ & VS & & & & \\
\hline $\begin{array}{l}\text { Dwelling unit } \\
\text { attribute/infrastructure }\end{array}$ & 1 & 2 & 3 & 4 & 5 & $\mathrm{SS}_{\mathrm{ac}}$ & Mean & SD & RSI \\
\hline Natural lighting/ventilation & 9 & 15 & 37 & 37 & 27 & 433 & 3.46 & 1.168 & 0.693 \\
\hline Location of the house & 6 & 17 & 44 & 32 & 26 & 430 & 3.44 & 1.110 & 0.688 \\
\hline Noise levels in house/estate & 9 & 17 & 37 & 35 & 27 & 429 & 3.43 & 1.180 & 0.686 \\
\hline Privacy & 13 & 19 & 32 & 32 & 29 & 420 & 3.36 & 1.279 & 0.672 \\
\hline Size of bedrooms & 6 & 26 & 36 & 43 & 14 & 408 & 3.26 & 1.064 & 0.653 \\
\hline $\begin{array}{l}\text { External appearance of the } \\
\text { house }\end{array}$ & 7 & 23 & 45 & 35 & 15 & 403 & 3.22 & 1.062 & 0.645 \\
\hline Housing typology & 12 & 20 & 45 & 27 & 21 & 400 & 3.20 & 1.185 & 0.640 \\
\hline Electricity/power supply & 16 & 20 & 37 & 32 & 20 & 395 & 3.16 & 1.247 & 0.632 \\
\hline $\begin{array}{l}\text { Rent/cost of acquiring the } \\
\text { house }\end{array}$ & 11 & 28 & 43 & 26 & 17 & 385 & 3.08 & 1.154 & 0.616 \\
\hline Bath/toilet facilities & 13 & 32 & 39 & 28 & 13 & 371 & 2.97 & 1.150 & 0.594 \\
\hline Sizes of living/dining spaces & 21 & 24 & 39 & 22 & 19 & 369 & 2.95 & 1.288 & 0.590 \\
\hline Type of building materials & 13 & 35 & 35 & 30 & 12 & 368 & 2.94 & 1.152 & 0.589 \\
\hline Number of bedrooms & 10 & 40 & 38 & 24 & 13 & 365 & 2.92 & 1.119 & 0.584 \\
\hline $\begin{array}{l}\text { Sizes of cooking/storage } \\
\text { spaces }\end{array}$ & 16 & 36 & 38 & 25 & 10 & 352 & 2.82 & 1.139 & 0.563 \\
\hline Water supply/sanitary service & 25 & 38 & 31 & 14 & 17 & 335 & 2.68 & 1.293 & 0.536 \\
\hline
\end{tabular}

Dissatisfactory aspects of dwelling units with RSI values less than 0.6 relate to inadequate service and living areas notably baths, toilets, cooking and storage spaces, number of bedrooms, quality of construction materials and lastly, water supply and sanitary services (Table 4). Pertinent to this discussion is the observation that all dissatisfactory functional spaces outlined above (except number of bedrooms and sizes of living spaces) accommodate diurnal tasks that are heavily dependent on supply of water to dwelling units. This observation underscores the pervading impact of water supply on satisfaction with dwelling units, confirming results presented in the preceding section regarding the inadequacy of this essential support service in the study area. It also furnishes further proof that satisfaction ratings in housing environments directly reflect adequacy and that one concept can be substituted for the other (Ibem et al., 2015).

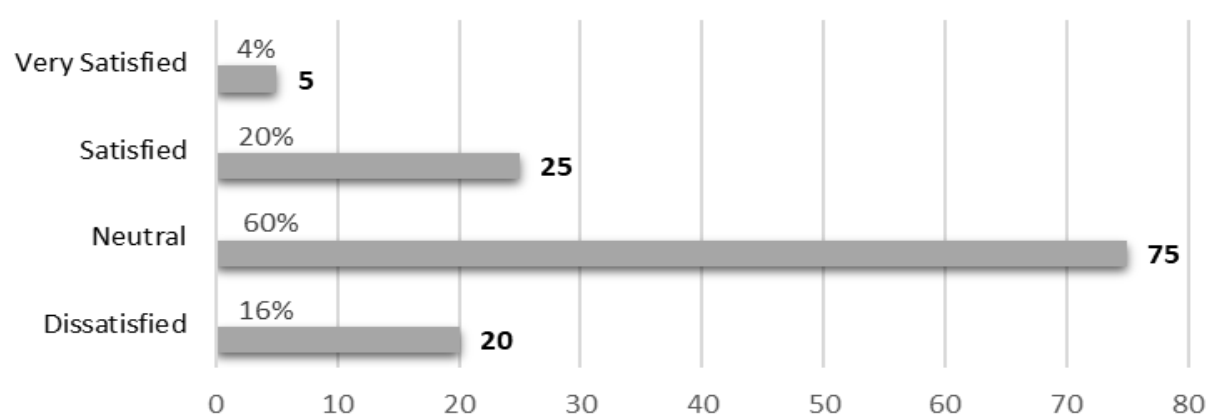

Figure 6 DUSS for dwelling unit attributes and infrastructure 
Overall, DUSS of 3.13 (SD 0.69) suggests that residents were satisfied with their dwelling unit and support infrastructure. This result, reflected in Figure 6, illustrates that $84 \%$ of respondents recorded DUSS values of 3.0 (neutral) and above. There were no very dissatisfied residents.

\subsection{Dimensions and Predictors of Satisfaction with Dwelling Unit Attributes and Infrastructure}

\subsubsection{Dimensions of satisfaction with dwelling unit attributes and infrastructure}

Results from PCA revealed three underlying components reflecting viewpoints of residents on satisfaction with dwelling unit attributes and infrastructure in the study area. In line with findings presented in Table 4, the first component describes housing design and cost, explaining over half $(25.34 \%)$ of the total variance in Table 5 . All items extracted for this component relate to aspects of dwelling unit design and planning, except rent and cost of acquiring the house. Ige and Evelyn (2018) present similar findings in their study of a Public Private Partnership estate in Akure, Southwest Nigeria where construction and design of dwelling units explained $65.55 \%$ variance of residential satisfaction scores.

Table 5 PCA of satisfaction with dwelling unit attributes and infrastructure

\begin{tabular}{|c|c|c|c|c|}
\hline Factor/component & $\begin{array}{l}\text { Factor } \\
\text { loading }\end{array}$ & $\begin{array}{l}\text { Eigen } \\
\text { value }\end{array}$ & $\begin{array}{c}\% \\
\text { variance }\end{array}$ & $\begin{array}{c}\% \\
\text { cum. }\end{array}$ \\
\hline \#1 Housing design and cost $(\alpha=0.846$, M 3.10, SD 0.781$)$ & & 3.80 & 25.34 & 25.34 \\
\hline Size of bedrooms & 0.779 & & & \\
\hline External appearance of the house & 0.726 & & & \\
\hline Sizes of living/dining spaces & 0.694 & & & \\
\hline Type of building materials & 0.674 & & & \\
\hline Number of bedrooms & 0.648 & & & \\
\hline Rent/cost of acquiring the house & 0.581 & & & \\
\hline Housing typology & 0.547 & & & \\
\hline Location of the house & 0.466 & & & \\
\hline $\begin{array}{l}\# 2 \text { Housing services and environmental conditions } \\
(\alpha=0.762, \mathrm{M} 3.06, \mathrm{SD} 0.864)\end{array}$ & & 2.71 & 18.07 & 43.41 \\
\hline Natural lighting/ventilation & 0.795 & & & \\
\hline Privacy & 0.695 & & & \\
\hline Water supply/sanitary services & 0.665 & & & \\
\hline Sizes of cooking/storage spaces & 0.556 & & & \\
\hline Bath/toilet facilities & 0.493 & & & \\
\hline \#3 Electricity supply and noise levels $(\alpha=0.544$, M 3.30, & SD 1.0) & 1.66 & 11.10 & 54.50 \\
\hline Electricity/power supply & 0.777 & & & \\
\hline Noise levels & 0.767 & & & \\
\hline
\end{tabular}

The second component describes service spaces as well as indoor environmental quality (IEQ) conditions and explain about $18 \%$ of the total variance in Table 5. Residents clustered natural lighting, ventilation and privacy together with service-zone functions specifically water supply and sanitary services, cooking and storage spaces and finally, bath and toilet facilities. Interestingly, the third component clusters electricity supply with noise levels, two variables closely related to power generation in the past few years (Stanley, 2016). Because many residents depended on generating sets for power, high levels of disturbance were associated with noise from generators. The low reliability value of 0.544 and high SD for this component (1.0) suggests that variations exist across the sample and imply that ratings for both electricity supply and noise levels differ remarkably across the different estates surveyed, in spite of both variables recording relatively high factor loadings in Table 5. This however component records 
the highest mean value of 3.30. Future studies at estate levels with larger samples will help in verifying this finding. Notwithstanding, the fact that electricity is clustered with noise suggests continued use of generators and that power supply remains an issue among residents of public housing estates in Northern Nigeria. Inadequate support services and infrastructure fosters dissatisfaction as illustrated in Table 4.

In sum, PCA reveals that residents view adequacy with dwelling unit attributes and infrastructure in terms of design and cost, service functions and environmental conditions as well as electricity supply and noise levels. This categorisation provides design and policy makers guidelines for planning future housing projects in the study area.

\subsubsection{Predictors of satisfaction with dwelling unit attributes and infrastructure}

CATREG regression established that the three components from the PCA significantly predict satisfaction with dwelling unit attributes and infrastructure as shown in Table 6. A combination of extracted components and tenant demographic variables significantly predict satisfaction with dwelling unit attributes and infrastructure with $F(20.54,18), \mathrm{p}=0.000$. The $\mathrm{R}^{2}$ value (0.777) indicates that the regression model explains $77.7 \%$ of the variance in satisfaction with dwelling subsystem variables.

Table 6 Predictors of satisfaction with dwelling unit attributes and infrastructure

\begin{tabular}{|c|c|c|c|c|c|}
\hline \multirow[t]{2}{*}{ Variables } & \multicolumn{2}{|c|}{ Standardized Coefficients } & \multirow{2}{*}{$\mathrm{df}$} & \multirow[t]{2}{*}{$\mathrm{F}$} & \multirow[t]{2}{*}{ Sig. } \\
\hline & Beta & $\begin{array}{l}\text { Bootstrap (1000) } \\
\text { Estimate of SE }\end{array}$ & & & \\
\hline \#1 Housing design and cost & .541 & .055 & 1 & 97.102 & .000 \\
\hline \#2 Housing services and environmental conditions & .362 & .055 & 1 & 42.550 & .000 \\
\hline \#3 Electricity supply and noise levels & .198 & .052 & 1 & 14.450 & .000 \\
\hline Number of bedrooms & .076 & .048 & 3 & 2.521 & .062 \\
\hline Employment & .065 & .039 & 2 & 2.699 & .072 \\
\hline Gender & .070 & .049 & 1 & 2.051 & .155 \\
\hline Tenure type & .054 & .043 & 1 & 1.563 & .214 \\
\hline Monthly income & .055 & .046 & 2 & 1.425 & .245 \\
\hline Age & .042 & .041 & 2 & 1.048 & .354 \\
\hline Number of persons in household & .034 & .044 & 1 & .611 & .436 \\
\hline Highest education & .013 & .032 & 1 & .164 & .687 \\
\hline Marital status & -.016 & .053 & 1 & .088 & .767 \\
\hline Length of stay & -.047 & .058 & 1 & .656 & .420 \\
\hline
\end{tabular}

Dependent variable: DUSS

Results from Table 6 reveal that number of bedrooms as well as employment both approach but fail to achieve significance at $p<0.05$ across data from the five public housing estates surveyed. This result suggests that among objective characteristics of dwelling units, the number of bedrooms in a dwelling unit is crucial to residential satisfaction in the Nigerian context as submitted by Ukoha and Beamish (1997). Future studies at estate levels would be beneficial in clarifying this finding. The result on employment confirms that residents in public service are more satisfied with their dwellings and support infrastructure than their counterparts in the private sector. Ibem and Aduwo (2013) echoing Elsinga and Heoskstra (2005) note that home ownership, the policy of owner-occupancy in our study being a prime example, is a significant predictor of residential satisfaction. 
While eight of the variables in the tenant subsystem record positive beta values, marital status and length of stay recorded negative beta values (Table 6). This implies that married respondents as well as those who have lived for longer periods within the estates tend to be dissatisfied with their dwellings. Married respondents are likely to have more responsibilities such as raising a family and are thus more likely to remain in a home for longer periods compared to single respondents unencumbered by family obligations. This in turn is likely to produce dissatisfaction over time especially for married respondents with changing family needs occupying inflexible dwelling units.

\section{CONCLUSION}

This study explored residents' satisfaction with dwelling units and supporting infrastructure in five selected estates across Northern Nigeria as such studies are rare in literature. The investigation assessed adequacy of dwelling units and services as well as residents' perception of the same variables to inform future housing developments in the region. Conclusions are summarised in four points. First, support services, especially water supply are grossly inadequate. Although electricity supply has improved, water supply and waste disposal leave enormous room for acute intervention by government and civic society. Second, satisfaction was highest with design related attributes notably natural lighting and ventilation, location of the house as well as noise, privacy, size of bedrooms, appearance, typology, electricity supply and cost of housing. Satisfaction was lowest with service and living areas notably baths, toilets, cooking and storage spaces, number of bedrooms, quality of construction materials and lastly, water supply and sanitary services. Third, residents perceive satisfaction with dwelling unit attributes and infrastructure in terms of design and cost, services and IEQ as well as electricity supply and noise levels. Lastly, factors influencing ways residents perceive their dwelling unit attributes and infrastructure significantly predict satisfaction within the estates.

Recommendations from the study target design, planning and policy-making. User perspectives ought to guide design of future projects. Attention to living areas, bedrooms, appearance of dwellings, materials for construction and cost is essential, as these were the most pertinent attributes of dwelling units influencing satisfaction from user perspectives. IEQ variables such as natural lighting and ventilation benefit from careful zoning of service functions as illustrated from the study findings. Additionally, the deplorable state of water supply requires support from Non-Governmental Organisations as well as self-help initiatives. The latter is more common in Southern regions of the country. However, specific policies supporting such initiatives are overdue for implementation in Northern regions of Nigeria. Finally, the finding that solar energy is now an alternative source of electricity supply at dwelling unit level ought to be supported by policies whereby dwellings are designed to generate power thus reducing the pressure on public power supply. This is especially pertinent across a region with enormous supplies of natural daylight all year round.

As indicated within the methodology, this study was not devoid of limitations. First, this was a cross-sectional survey of residents' perceptions across several disparate estates in Northern Nigeria. Longitudinal surveys across the region will proffer more robust, stable and generalisable results. Secondly, future studies would benefit from in-depth investigations of individual estates, as residential satisfaction is contextual. While results from this explorative survey provides an overview of the situation across the region, policy makers will benefit more from micro rather than macro level analyses. Finally, sustainability and resilience are largely studied within social and neighbourhood environments. Similar analyses at neighbourhood levels in the region would enrich our understanding satisfaction and adequacy of housing environments and support infrastructure. 


\section{ACKNOWLEDGEMENT}

Authors acknowledge the support of all respondents without whom this study would not have been possible. No financial support was received for this study.

\section{REFERENCES}

Adegbile, M., Onifade, V., \& Adedire, F. (2020). Impacts of Residential Environments on Housing Satisfaction in Selected Neighbourhoods of Ogun State, Nigeria. In Journal of Architcture, Planning \& Construction Management (Vol. 10, Issue 1).

Adegbile, M., Onifade, V., \& Solanke, P. . (2019). Influence of Housing Attributes on Housing Satisfaction in Selected Residential Areas of Ogun State, Nigeria. Environmental Technology and Science Journal, 10(1), 1-15. https://ir.unilag.edu.ng/handle/123456789/8675

Adzande, P. (2013). Towards efficient provision of physical infrastructure in residential areas of Makurdi, Nigeria. In S. Laryea \& S. A. Agyepong (Eds.), Procs 5th West Africa Built Environment Research Conference (pp. 1159-1171).

Aragonés, J. I., Amérigo, M., \& Pérez-López, R. (2017). Residential Satisfaction and Quality of Life (pp. 311-328). https://doi.org/10.1007/978-3-319-31416-7_17

Babalola, O., Ibem, E. O., \& Ezema, I. C. (2019). Implementation of lean practices in the construction industry: A systematic review. In Building and Environment (Vol. 148, pp. 34-43). https://doi.org/10.1016/j.buildenv.2018.10.051

Bixley, B., \& Yamane, T. (1965). Statistics: An Introductory Analysis. In The Canadian Journal of Economics and Political Science (2nd ed., Vol. 31, Issue 1). Harper and Row. https://doi.org/10.2307/139661

David Jiboye, A. (2012). Post-occupancy evaluation of residential satisfaction in Lagos, Nigeria: Feedback for residential improvement. Frontiers of Architectural Research, 1(3), 236-243. https://doi.org/10.1016/j.foar.2012.08.001

Durodola, O., Oloke, O. ., \& Akunnaya, O. . (2016). Co-operative housing and basic infrastructure provision: A conceptual framework for effective Public Private Partnership. http://eprints.covenantuniversity.edu.ng/8189/1/Unilag Journal.pdf

Elsinga, M., \& Hoekstra, J. (2005). Homeownership and housing satisfaction. Journal of Housing and the Built Environment, 20(4), 401-424. https://doi.org/10.1007/s10901-0059023-4

Equere, E., Ibem, E., \& Alagbe, O. (2020). Towards city resilience: the influence of sociocultural and economic features of housing on population growth in public residential estates. Journal of Regional and City Planning, 31(2), 164-179. https://doi.org/10.5614/jpwk.2020.31.2.4

Etminani-Ghasrodashti, R., Majedi, H., \& Paydar, M. (2017). Assessment of Residential Satisfaction in Mehr Housing Scheme: A Case Study of Sadra New Town, Iran. Housing, Theory and Society, 34(3), 323-342. https://doi.org/10.1080/14036096.2017.1298536

Fakere, A. A., Folorunso, C. O., Arayela, O., \& Adedeji, Y. M. (2018). Participatory predictors of users' satisfaction with housing infrastructure in Akure, Nigeria. Facilities, 36(13-14), 696-710. https://doi.org/10.1108/F-10-2017-0103

Field, A. (2013). Discovering statistics using IBM SPSS statistics. In Statistics (Vol. 58).

Galster, G. (1987). Identifying the correlates of dwelling satisfaction:An empirical critique. Environment and Behavior, 19(5), 539-568. https://doi.org/10.1177/0013916587195001

Hussaini, I. U., Abubakar, S. K., Danmaraya, M. A., Sumaila, S. A., \& Ibrahim, S. K. (2019). Sustainable urban development and the challenges of urban sprawl in 'Abuja' the federal capital city of Nigeria. West Africa Built Environment Research Conference, 1031-1050. https://doi.org/10.33796/waberconference2019.74 
Ibem, Eziyi O., \& Amole, D. (2013). Residential Satisfaction in Public Core Housing in Abeokuta, Ogun State, Nigeria. Social Indicators Research, 113(1), 563-581. https://doi.org/10.1007/s11205-012-0111-z

Ibem, Eziyi O., Opoko, P. A., \& Aduwo, E. B. (2017). Satisfaction with Neighbourhood Environments in Public Housing: Evidence from Ogun State, Nigeria. Social Indicators Research, 130(2), 733-757. https://doi.org/10.1007/s 11205-015-1188-y

Ibem, Eziyi Offia. (2013). Accessibility of Services and Facilities for Residents in Public Housing in Urban Areas of Ogun State, Nigeria. Urban Forum, 24(3), 407-423. https://doi.org/10.1007/s12132-012-9185-6

Ibem, Eziyi Offia, \& Aduwo, E. B. (2013). Assessment of residential satisfaction in public housing in Ogun State, Nigeria. Habitat International, 40, 163-175. https://doi.org/10.1016/j.habitatint.2013.04.001

Ibem, Eziyi Offia, \& Alagbe, O. A. (2015). Investigating dimensions of housing adequacy evaluation by residents in public housing: Factor analysis approach. Facilities, 33(7-8), 465-484. https://doi.org/10.1108/F-02-2014-0017

Ige, V., \& Evelyn, O. I. (2018). Public Private Partnership Residential Estates: Beneficiaries' Satisfaction Assessment. Discovery, 54(272), 298-303.

Lar. (2019). Violence and Insecurity in Northwest Nigeria: Exploring the Role and Resilience of Local Actors. African Conflict and Peacebuilding Review, 9(2), 123. https://doi.org/10.2979/africonfpeacrevi.9.2.07

Maina, J. J., Garba Zarafi, I., \& Stanley, A. M. (2018). Unsatisfactory Amenities: Rethinking Management of University Staff Housing of Public Universities in Nigeria. In Savanna (Vol. 24, Issue 3). https://journal.abu.edu.ng/savannah/index.php/sav/article/view/90

Mammadi, A., Baba, H. M., Tukur, S., Muhammad, A. A., \& Abdullahi, U. (2020). Measuring Residents Satisfaction Levels of Public Housing in Maiduguri Metropolis of Borno State, Nigeria. Path of Science, 6(3), 3001-3020.

Morakinyo, K. O. ., Okunola, A. S. ., Musibau, L. ., Odewande, A. G. ., \& Dada, O. (2014). An assessment of housing infrastructural provision in public housing: A case study of Bashorun Housing Estate Akobo, Ibadan Oyo State, Nigeria. Civil and Environmental Research, 6(13), 102-113. www.eajournals.org

Morris, E. W., \& Winter, M. (1975). A Theory of Family Housing Adjustment. Journal of Marriage and the Family, 37(1), 79. https://doi.org/10.2307/351032

Nigerian Investment Promotion Comission. (2020). Bouncing back: Nigeria Economic Sustainability Plan. https://nipc.gov.ng/wp-content/uploads/2020/09/NG-EconomicSustainability-Plan-2020.pdf?

Ogu, V. I. (2002). Urban residential satisfaction and the planning implications in a developing world context: The example of Benin City, Nigeria. International Planning Studies, 7(1), 37-53. https://doi.org/10.1080/13563470220112599

Oladapo, A. (2006). A Study of Tenants' Maintenance Awareness, Responsibility and Satisfaction in Institutional Housing in Nigeria. International Journal of Strategic Property Management, 10(4), 217-231. https://doi.org/10.3846/1648715x.2006.9637554

Oladapo, R. A., \& Adebayo, M. A. (2014). Effects of Housing Facilities on Residents' Satisfaction in Osogbo, Osun State, Nigeria. In Covenant Journal of Research in the Built $\begin{array}{lllll}\text { Environment (VJRBE) } & \text { (Vol. } & \text { Issue }\end{array}$ https://journals.covenantuniversity.edu.ng/index.php/cjrbe/article/view/165

Oluwunmi, A. O., Akinjare, O. A., \& Izobo-Martins, O. O. (2012). User's Satisfaction with Residential Facilities in Nigerian Private Universities: A Study of Covenant University. Transnational Journal of Science and Technology, 2(11), 89-112.

Omolabi, A. . (2018). Neighbourhood Revitalisation and Housing Satisfaction: Enhancing Residents' Quality of Life in Public Low-Income Housing in Lagos Metropolis Nigeria. 
University of KwaZulu-Natal, Durban.

Salisu, U. O., Odulaja, A. O., Ogunseye, N. O., Fasina, S. O., \& Okunubi, S. A. (2019). Residents' Satisfaction with Public Housing in Lagos, Nigeria. Ghana Journal of Geography, 11(1), 180-200.

Stanley, A. M. (2016). Impact of Electric Power Generators' Variables on Noise-level Generation in Indoor Building Environments. The International Journal of the Constructed Environment, 8(1), 17-29. https://doi.org/10.18848/2154-8587/cgp/v08i01/17-29

Ukoha, O. M., \& Beamish, J. O. (1997). Assessment of residents' satisfaction with public housing in Abuja, Nigeria. Habitat International, 21(4), 445-460. https://doi.org/10.1016/S0197-3975(97)00017-9

Urbanet. (2018). Urbanisation and Urban Development in Nigeria. https://www.urbanet.info/urban-development-nigeria-infographics/

Wakuma Kitila, A. (2019). Factors Affecting Housing Adequacy and Accessibility in Harar City, Harari Regional State, Ethiopia. East African Journal of Social Sciences and Humanities, 4(1), 1-26. https://haramayajournals.org/index.php/ejsh/article/view/856

World Bank. (2020). Urban land area (sq. $\mathrm{km})$ - Nigeria | Data. https://data.worldbank.org/indicator/AG.LND.TOTL.UR.K2?locations=NG

Zaki, Y.M., Suleiman, N. E., \& Teku, Y. (2015). An assessment of the conformity of housing standards in the rising urban development in Kaduna State. In S. Laryea \& R. Leiringer (Eds.), West Africa Built Environment Research Conference (pp. 49-59). 